\title{
Antimicrobial Susceptibility Pattern of Oral Viridans Group Streptococci in Children at Risk of Infective Endocarditis
}

\author{
Morva Moudi', Nilgoon Pasdar², Kazem Babazadeh³, Zahra Shahandeh", \\ Farahnaz Sadighian ${ }^{4}$ \\ ${ }^{1}$ Student Research Committee, Babol University of Medical Sciences, Babol, Iran \\ ${ }^{2}$ Oral Health Research Center, Health Research Institute, Babol University of Medical Sciences, Babol, Iran \\ ${ }^{3}$ Non-Communicable Pediatric Diseases Research Center, Health Research Institute, \\ Babol University of Medical Sciences, Babol, Iran \\ ${ }^{4}$ Department of Laboratory Sciences, Faculty of Paramedical Sciences, Babol University of Medical Sciences, \\ Babol, Iran
}

SUMMARY

Infective endocarditis (IE) is an important clinical disease in children with a mortality rate of 11.6\%. Prophylaxis with antibiotics is one of the most commonly used methods in children at risk of IE; therefore, the evaluation of antibiotic resistance seems necessary in view of its increasing trend. This study aimed to determine the antibiotic susceptibility pattern of oral viridans group streptococci (VGS) isolated from the dental plaque of children at risk of IE.

Fifty-one plaque samples were obtained from children aged 3 to 12 years old in the period from April to July 2018. Samples were obtained with sterile swabs and were transferred to the laboratory in Brain Heart Infusion (BHI) Broth. Samples were immediately cultivated on Columbia blood agar. After identifying VGS, antimicrobial susceptibility test (AST) was performed using Mueller-Hinton agar (MHA) with sheep's blood and E-test strips for selected antibiotics. The minimum inhibitory concentration (MIC) was determined for each isolate and the results were reported as sensitive, intermediate and resistant.

Fifty-one VGS bacteria were isolated from children with an average age of $7.3 \pm 2.5$ years. The highest resistance was observed for azithromycin in $36(70.6 \%)$ isolates and then cefazolin in $35(68.6 \%)$ isolates. The highest susceptibility was observed for amoxicillin in $46(90.2 \%)$ isolates.

Based on the findings of this study, amoxicillin is the most effective option for prophylaxis in children. Furthermore, cefazolin should be used with caution because bacteria resistant to this antibiotic can transfer resistance genes to other bacteria.

Key words: endocarditis, bacterial, dental care for children, viridans Streptococci, microbial sensitivity tests, anti-bacterial agents 


\section{INTRODUCTION}

Infective endocarditis (IE) is an important systemic disease that may occur in patients with heart problems undergoing invasive dental procedures (1). This rare yet life-threatening disease has an overall mortality rate of $25 \%$, even with the best treatments. Almost all structural heart disorders can be a risk factor for IE. Also, in developing countries, rheumatic heart disease (RHD) is the most prevalent predisposing factor for IE. Although Streptococci and Staphylococci together are responsible for approximately $80 \%$ of IE cases, the proportion of these two groups varies in different regions over time. In Asian and African countries, $32 \%$ of IE cases are caused by Streptococci and among them $23 \%$ is caused by the viridans group (2). Viridans group Streptococci (VGS) are gram-positive cocci and a major part of the mouth flora (3). They can cause bacteremia leading to IE following invasive dental procedures such as tooth extraction $(1,4)$. The prevalence of bacteremia caused by Streptococci and especially VGS following tooth extraction has been highly $(18 \%-85 \%)$ reported (5). Upon Streptococci entering the blood stream and causing bacteremia, the organism binds to the valvular endothelial site in predisposed patients, mediated by factors such as dextran and FimA (surface proteins known as adhesions). Platelet aggregation occurs following vegetation on the heart valve, which plays an important role in the pathogenicity of IE (2).

Despite recent therapeutic advances, IE disease in children is an important and complex clinical issue with a mortality rate of $11.6 \%$ (6). Recent studies have shown that $39.5 \%$ of IE cases in children are due to Streptococci. Also, Streptococci are the main cause of IE in children suffering from congenital heart disease (CHD) (7). Due to the high prevalence and mortality rate of IE, prophylaxis with antibiotics is used as a preventive method with high risk patients. Owing to the role of VGS in IE, most preventive efforts are focused on oral health (2). According to protocols set by the European Society of Cardiology (ESC) and the American Heart Association (AHA), the most commonly prescribed antibiotic as prophylactic procedure is oral amoxicillin. In cases of allergies or the inability to receive oral medication, other antibiotics including cephalexin, clarithromycin, cefazolin, clindamycin, azithromycin and ceftriaxone are used $(8,9)$. On the other hand, various studies have shown different rates and pat- terns of antibiotic resistance in VGS throughout the world $(10-14)$. The possibility of increased resistance to beta-lactams and other antimicrobial agents raises important concerns relating to this group of bacteria (15). In recent years, VGS have gained attention as antibiotic resistance gene reservoirs and carriers to other pathogenic organisms such as Streptococcus pneumonia and Streptococcus pyogenes (10). Furthermore, the widespread use of antibiotics in medical and agricultural settings has led to the rise of multi-drug resistant (MDR) bacteria (16).

Due to the limited number of published studies regarding resistance pattern of VGS and the antibiotics which are used in the prophylaxis of children at risk of IE, along with the increased rate of antibacterial resistance in this group of bacteria, this study aimed to determine the antibiotic susceptibility pattern of VGS isolated from the dental plaque of children who are at risk of IE.

\section{PARTICIPANTS AND METHODS}

In this cross sectional study, the clinical specimens obtained from dental plaque of 51 children at risk of IE aged from 3 to 12 years old were referred to Amirkola Children's Hospital (Babol University of Medical Sciences, Babol, Iran) and Rohani Hospital (Babol University of Medical Sciences, Babol, Iran) from April to July 2018, with written consent from their parents. Patients were selected according to AHA guidelines (17). The inclusion criteria was the lack of antibiotic use in the past two weeks. The protocol of this study was approved by the ethical committee of Babol University of Medical sciences, Babol, Iran (ethical number: IR.MUBABOL.REC. 1397.005)

Culture, isolation, identification and antibiotic susceptibility testing (AST): Dental plaque swabs in tubes containing $0.5 \mathrm{ml}$ of Brain Heart Infusion (BHI) broth (Himedia, India) were transferred on ice to the microbiology laboratory at the faculty of Paramedicine, Babol University of Medical Sciences. In the laboratory, samples were immediately cultivated on Columbia blood agar (Merck, Germanycontaining $5 \%$ sheep blood) and incubated for 24 to 48 hours at $35^{\circ} \mathrm{C}$, with a $\mathrm{CO} 2$ pressure of $5-10 \%$. Following growth, gram stain slides were prepared from suspected needle sized colonies which displayed $\alpha$-hemolysis (18). Upon identifying grampositive cocci in diplococci or chain formations, biochemical tests such as catalase (using the identi- 
fication of $3 \%$ hydrogen peroxide), susceptibility to optochin disk and bile solubility test were performed on the colonies. Gram-positive cocci that were catalase negative, resistant to optochin disk and 10\% sodium deoxycholate [bile salts] were identified as viridans streptococci and underwent AST (19).

To perform AST, E-test strips (Liofilchem ${ }^{\circledR}$, Italy) were used for amoxicillin, cefazolin, ceftriaxone (beta-lactams), azithromycin (macrolides), and clindamycin (lincosamide) on the isolated bacteria using standard protocols. First, a suspension equivalent to 0.5 McFarland standard solution was prepared from each bacterial isolate and then lawn culture was carried out on Mueller-Hinton agar (MHA) (Himedia, India) with 5\% sheep blood using a sterile swab. Subsequently, a strip for each type of antibiotic was placed on the culture medium and incubated for $20-24$ hours at $35^{\circ} \mathrm{C}$ (5 culture mediums for each bacterial isolate) (20). Following the incubation period, the minimum inhibitory concentration (MIC) was determined for each isolate and the results were reported as sensitive, intermediate and resistant according to the manufacturer's guidelines. Based on the guidelines used in this study, there is no intermediate interpretation for amoxicillin and cefazolin. The Streptococcus pneumoniae (ATCC ${ }^{\circledR} 49619^{\mathrm{TM}}$ ) standard strain was used as a quality control measure in this study (20). Bacterial isolates that were resistant to at least three antibiotics from different families (beta-lactams, macrolides or lincosamide) were considered MDR (21). Data were statistically analyzed using SPSS22 software.

\section{RESULTS}

In this study, 51 VGS bacteria were isolated from the dental plaque samples of 51 children, with the mean age of $7.3 \pm 2.5$ years, including $29(56.9 \%)$

Table 1. Antibiotic resistance patterns of VGS isolated from the dental plaque of children

\begin{tabular}{c|c|c|c}
\hline \hline Antibiotics & $\begin{array}{c}\text { Sensitive } \\
\mathrm{N}(\%)\end{array}$ & $\begin{array}{c}\text { Intermediate } \\
\mathrm{N}(\%)\end{array}$ & $\begin{array}{c}\text { Resistant } \\
\mathrm{N}(\%)\end{array}$ \\
\hline Ceftriaxon & $45(88.2)$ & $3(5.9)$ & $3(5.9)$ \\
\hline Amoxcillin & $46(90.2)$ & $*$ & $5(9.8)$ \\
\hline Clindamycin & $45(88.2)$ & $1(2)$ & $5(9.8)$ \\
\hline Azitromycin & $9(17.6)$ & $6(11.8)$ & $36(70.6)$ \\
\hline Cefazolin & $16(31.4)$ & $*$ & $35(68.6)$ \\
\hline \hline
\end{tabular}

girls and $22(43.1 \%)$ boys. AST results based on the MIC values obtained from the isolated bacteria are shown in Table 1.

The highest resistance was towards azithromycin in $36(70.6 \%)$ isolates and the highest susceptibility was observed for amoxicillin in 46 (90.2\%) isolates. Seven $(13.7 \%)$ isolates were susceptible to all antibiotics. Twenty-eight (54.9\%) isolates were resistant to at least two antibiotics from different families (azithromycin and cefazolin) and four (7.8\%) isolates were MDR.

\section{DISCUSSION}

VGS are predominant part of the mouth flora and may act as opportunistic pathogens in immunocompromised patients, particularly patients at risk of IE (3). Despite recent therapeutic advances, this disease had a mortality rate of $11.6 \%$ in children (6). Oral Streptococci are the cause of $39.5 \%$ of bacterial IE cases in children (7). All strategic committees throughout the world suggest antibiotic prophylaxis for high risk patients undergoing invasive dental procedures and reports have shown that the lack of antibiotic prophylaxis implementation can heighten the incidence rate of IE (9). However, a universal antimicrobial treatment protocol for IE in children has not been recommended and international cooperation seems to be necessary in this regard (7).

In the current study, the highest resistance to antibiotics was for azithromycin (70.6\%). Azithromycin is the most commonly used macrolide in the treatment of lower respiratory infections in children (22) and is used as an alternative or complementary antibiotic with amoxicillin for the treatment of mycoplasma respiratory infections in children over five years of age (23). Azithromycin's half life is high, so the chances of expanding bacterial resistance (due to the presence of the ermB gene, the production of inactivating enzymes, or the presence of efflux systems coded by mef or msr genes) increase $(19,24)$. Each of the aforementioned reasons can be a possible explanation for the high resistance of the isolates against azithromycin in this study. The results of a study performed by Dhotre et al. are in line with the present study (25). Research performed on the antibiotic susceptibility of oral VGS from 2005 to 2018 throughout the world show the increasing resistance to the antibiotics investigated in the present study. It is noteworthy that a sudden increase in resistance to clindamycin and ceftriaxone 
was observed from 2009 to 2011, while a decrease in resistance to amoxicillin and azithromycin was seen during the same period. Nevertheless, after 2011, the resistance to amoxicillin and azithromycin increased more rapidly in comparison with the resistance to clindamycin and ceftriaxone (10, 11, 14,15, 24 - 31). It seemed that alterations in the type and amount of the used antibiotics in these years led to this trend. In the present study, the relatively high susceptibility of the VGS isolates to amoxicillin (90.2\%) shows that the resistance to this group of antibiotics is not prevalent in this region. Amoxicillin and possibly other penicillin (e.g. ampicillin) can be effective on VGS, thus making them trustworthy options for treatment and prophylaxis. Chunduri et al. in India and William et al. in Uganda have performed similar studies, where $90 \%$ and more than $60 \%$ of the studied VGS isolates were susceptible to amoxicillin, respectively (32-33). Nevertheless, Suzuk et al. in Turkey reported high resistance to beta-lactams (ampicillin and penicillin) (3). Beta-lactams are the most prevalent antibiotics for treatment in society. Their receptors (PBP) on the bacterial cell wall can undergo changes due to transformation and homologous recombination which can lead to the emergence of resistant strains from this group. These strains have great significance due to the fact that these resistant strains can be gene carriers and transfer resistance genes to other similar groups such as pneumococci and other pathogenic bacteria $(3,31,33)$. Cefazolin, a type of beta-lactam, is the drug of choice for parenteral prophylaxis before surgery due to its desirable properties such as the beneficial effect on microorganisms (34). The increased resistance to cefazolin $(68.6 \%)$ in this study may be due to changes in PBPs, as a result of excessive consumption.

In the current study, the resistance rate to clindamycin is low (9.8\%). The use of clindamycin is beneficial. Since it can be administered orally or intravenously, it has great oral absorbance, good circulation within soft tissues and the ability to inhibit toxin production and virulence factors in several bacterial species. Based on the high rate of susceptibility observed in this work $(88.2 \%)$, it would seem that clindamycin is a suitable alternative in cases with penicillin allergy (35). Chunduri et al. similarly found that $85 \%$ of VGS are susceptible to clindamycin (32). However, Kim et al. showed that less than $70 \%$ of Streptococci isolates are susceptible to clindamycin in Boston, USA (35).
Emerging MDR strains of VGS, as important pathogens, cause great difficulty in the treatment of infections (36). Over the years, many different reports about the prevalence of MDR strains of this group have been published. In a study performed by Dhotre et al., $11 \%$ of VGS isolates were resistant to eight antibiotics (37). Also, William et al. reported that approximately $14 \%$ of viridans Streptococci were resistant to more than two antibiotics (33). In the present research, $7.8 \%$ of the studied isolates were MDR. Given the importance of their role as the cause of IE, these strains not only make general prophylaxis difficult but also further complicates the antibiotic resistance pattern in this region (30). Also, regular oral hygiene and dental prophylaxis, performing dental procedures after disinfecting the oral environment and determining the susceptibility patterns of antibiotics in high risk patients is essential $(38-40)$. This study has some limitations that need to be addressed. A relatively small sample size is a limitation of the current study. Lack of correct information about the patients' antimicrobial use history, a factor which may have influenced antimicrobial susceptibility, was another limitation. Such evaluation should be included in future studies.

\section{CONCLUSION}

In conclusion, the present study showed that VGS in children who are at risk for IE is susceptible to amoxicillin, which is the first choice of antibiotic and an effective option for prophylaxis. Also, due to the high prevalence of resistance to some antibiotics such as azithromycin and cefazolin, it is crucial to determine the antibiotic susceptibility patterns of the bacteria in this region. Also, to prevent the emergence and evolution of resistant strains, the prescription and appropriate use of antibiotics must be carefully managed.

\section{Acknowledgement}

This study was approved and financially supported by the deputy of research and technology of Babol University of Medical Sciences, Babol, Iran.

\section{Conflict of interest}

The authors declare that there is no conflict of interest in this study. 


\section{References}

1. Nemoto $H$, Nomura R, Ooshima T, Nakano K. Distribution of amoxicillin-resistant oral streptococci in dental plaque specimens obtained from Japanese children and adolescents at risk for infective endocarditis. J Cardiol 2013; 62(5):296-300.

https://doi.org/10.1016/j.jjcc.2013.05.008

2. Holland TL, Baddour LM, Bayer AS, et al. Fowler VG Jr. Infective endocarditis. Nat Rev Dis Primers 2016; 2:16059. https://doi.org/10.1038/nrdp.2016.59

3. Süzük S, Kaşkatepe B, Çetin M. Antimicrobial susceptibility against penicillin, ampicillin and vancomycin of viridans group Streptococcus in oral microbiota of patients at risk of infective endocarditis. Infez Med 2016;24(3):190-3.

4. Goldsmith C, Hara Y, Sato T, et al. Comparison of antibiotic susceptibility in viridans group streptococci in low and high antibiotic-prescribing General Practices. J Clin Pharm Ther 2015; 40(2):204-7. https://doi.org/10.1111/jcpt.12245

5. Poveda-Roda R, Jiménez $\mathrm{Y}$, Carbonell E, et al. Bacteremia originating in the oral cavity. A review. Med Oral Patol Oral Cir Bucal 2008;13(6):E355-E362.

6. Kelchtermans J, Grossar L, Eyskens B, et al. Clinical Characteristics of Infective Endocarditis in Children. Pediatr Infect Dis J 2019; 38(5):453-8. https://doi.org/10.1097/INF.0000000000002212

7. Dixon G, Christov G. Infective endocarditis in children: an update. Curr Opin Infect Dis 2017; 30(3):257-67.

https://doi.org/10.1097/QCO.0000000000000370

8. Seymour RA. Dentistry and the medically compromised patient. Surgeon 2003; 1(4):207-14. https://doi.org/10.1016/S1479-666X(03)80019-7
9. Thornhill $\mathrm{MH}$, Dayer $\mathrm{M}$, Lockhart PB, Prendergast B. Antibiotic prophylaxis of infective endocarditis. Curr Infect Dis Rep 2017; 19(2):9. https://doi.org/10.1007/s11908-017-0564-y

10. Abu-zineh R, Dar-Odeh N, Shehabi A. Macrolide resistance genes and virulence factors of common viridans Streptococci species colonizing oral cavities of patients in Jordan. Oral Health Dent Manag 2015;14:337-41.

11. Chitra N, Mangayarkarasi V, Balakrishnan D, Smiline Girija AS. Resistance Patterns of Viridans Group of Streptococci isolated in transient bacteremia after third molar surgery. Int J Curr Microbiol App Sci 2015;4(6):78-85.

12. Parks T, Barrett L, Jones N. Invasive streptococcal disease: a review for clinicians. Br Med Bull 2015; 115(1):77-89.

https://doi.org/10.1093/bmb/ldv027

13. Prakash D, Ramesh K, Gopinath N, et al. Antibacterial efficacy of Syzygium aromaticum extracts on multi-drug resistant Streptococcus mutans isolated from dental plaque samples. J Biochem Technol 2014;3(5):155-7.

14. Rotimi V, Salako N, Mokaddas E, et al. High frequency of isolation of antibiotic-resistant oral Viridans streptococci from children in Kuwait. J Chemother 2005; 17(5):493-501. https://doi.org/10.1179/joc.2005.17.5.493

15. Chun S, Huh HJ, Lee NY. Species-specific difference in antimicrobial susceptibility among viridans group streptococci. Ann Lab Med 2015; 35(2):205-11.

https://doi.org/10.3343/alm.2015.35.2.205

16. Park S-C, Park Y, Hahm K-S. The role of 
antimicrobial peptides in preventing multidrugresistant bacterial infections and biofilm formation. Int J Mol Sci 2011;12(9):5971-92. https://doi.org/10.3390/ijms12095971

17. Garg P, Ko DT, Bray Jenkyn KM, et al. Infective Endocarditis Hospitalizations and Antibiotic Prophylaxis Rates Before and After the 2007 American Heart Association Guidelines Revision. Circulation 2019; 140(3):170-80. https://doi.org/10.1161/CIRCULATIONAHA.118.0 $\underline{37657}$

18. Shafiee F, Moghadamnia AA, Shahandeh Z, et al. Evaluation of the antibacterial effects of aqueous and ethanolic leaf extracts of Aloysia Citriodora (Lemon verbena) on Streptococcus mutans and Streptococcus sobrinus. Electron Physician 2016;8(12):3363.

https://doi.org/10.19082/3363

19. Carroll KC BJ, Morse S. Jawetz, Melnick\& Adelbergs medical microbiology. 17ed. Caroll KC HJ, editor. Toronto: McGraw-Hill; 2016.

20. Gloria-Garza MA, Gomez-Flores R, De La GarzaRamos MA, et al. In vitro antimicrobial activity of Ruta chalepensis methanol extracts against the cariogenic Streptococcus mutans. Afr J Microbiol Res 2013;7(46):5234-7. https://doi.org/10.5897/AJMR2013.5859

21. Basak S, Singh P, Rajurkar M. Multidrug resistant and extensively drug resistant bacteria: A study. J Pathog 2016;2016:4065603. https://doi.org/10.1155/2016/4065603

22. Liu S, Zheng $\mathrm{Y}, \mathrm{Wu} \mathrm{X}$, et al. Early target attainment of azithromycin therapy in children with lower respiratory tract infections. J Antimicrob Chemother 2018; 73(10):2846-50. https://doi.org/10.1093/jac/dky273

23. Saffar MJ. Acute Lower Respiratory Tract Infections Including Pneumonia; Clinical Approach to Diagnosis and Treatment: A Narrative Review. J Clin Exc 2014;3(1):29-45.

24. Malhotra-Kumar S, Lammens C, Coenen S, et al. Effect of azithromycin and clarithromycin therapy on pharyngeal carriage of macrolide-resistant streptococci in healthy volunteers: a randomised, double-blind, placebo-controlled study. Lancet 2007; 369(9560):482-90. https://doi.org/10.1016/S0140-6736(07)60235-9

25. Dhotre S, Jahagirdar V, Suryawanshi N, et al. Assessment of periodontitis and its role in viridans streptococcal bacteremia and infective endocarditis. Indian Heart J 2018; 70(2):225-32. https://doi.org/10.1016/j.ihj.2017.06.019

26. Borji A, Naghavi A, Borji H. An investigation on drug resistance of viridance group streptococci isolated from 3-12 years healthy individuals. Zahedan. J Res Med Sci 2010;12(4):28-32.

27. Fani M, Kohanteb J, Dayaghi M. Inhibitory activity of garlic (Allium sativum) extract on multidrug-resistant Streptococcus mutans. J Indian Soc Pedod Prev Dent 2007; 25(4):164-8. https://doi.org/10.4103/0970-4388.37011

28. Geethu M, Prabhu N, Jasmine M. Antimicrobial susceptibility trends among viridan streptococci isolates from cases of endocarditis from 2007-2009. Ann Biol Res 2010;1(1):130-3.

29. Groppo FC, Castro FM, Pacheco AB, et al. Antimicrobial resistance of Staphylococcus aureus and oral streptococci strains from high-risk endocarditis patients. Gen Dent 2005; 53(6):410-3.

30. Karikalan S, Mohankumar A. Studies on ampicillin resistant plasmid of Streptococcus mutans isolated from dental caries patients. Biosc Biotech Res Comm 2016;9(1):151-6. https://doi.org/10.21786/bbrc/9.1/23

31. Aslam B, Wang W, Arshad MI, et al. Antibiotic resistance: a rundown of a global crisis. Infect Drug Resist 2018; 11:1645-58. https://doi.org/10.2147/IDR.S173867

32. Chunduri NS, Madasu K, Goteki VR, et al. Evaluation of bacterial spectrum of orofacial infections and their antibiotic susceptibility. Ann Maxillofac Surg 2012; 2(1):46-50. https://doi.org/10.4103/2231-0746.95318

33. William B, Rwenyonyi CM, Swedberg G, Kironde F. Cotrimoxazole prophylaxis specifically selects 
for cotrimoxazole resistance in Streptococcus mutans and Streptococcus sobrinus with varied polymorphisms in the target genes folA and folP. Int J Microbiol 2012;2012:916129.

https://doi.org/10.1155/2012/916129

34. Hussain Z, Curtain C, Mirkazemi C, et al. Prophylactic Cefazolin Dosing and Surgical Site Infections: Does the Dose Matter in Obese Patients? Obes Surg 2019; 29(1):159-65. https://doi.org/10.1007/s11695-018-3497-0

35. Kim MK, Chuang S-K, August M. Antibiotic resistance in severe orofacial infections. J Oral Maxillofac Surg 2017; 75(5):962-8.

https://doi.org/10.1016/j.joms.2016.10.039

36. Ang JY, Asmar BI. Multidrug-resistant viridans streptococcus (MDRVS) osteomyelitis of the mandible successfully treated with moxifloxacin. South Med J 2008; 101(5):539-40. https://doi.org/10.1097/SMJ.0b013e3181684ee3
37. Dhotre S, Dharne M, Potdar S, et al. Viridians Group Streptococci in Patients Undergoing Tooth Extraction. Eur J Gen Med 2015;12(3):227-33. https://doi.org/10.15197/ejgm.01406

38. Cahill TJ, Harrison JL, Jewell P, et al. Antibiotic prophylaxis for infective endocarditis: a systematic review and meta-analysis. Heart 2017; 103(12):937-44.

https://doi.org/10.1136/heartjnl-2015-309102

39. Vogkou CT, Vlachogiannis NI, Palaiodimos L, Kousoulis AA. The causative agents in infective endocarditis: a systematic review comprising 33,214 cases. Eur J Clin Microbiol Infect Dis 2016; 35(8):1227-45.

https://doi.org/10.1007/s10096-016-2660-6

40. Błochowiak KJ. Dental treatment and recommended management in patients at risk of infective endocarditis. Kardiochir Torakochirurgia Pol 2019; 16(1):37-41. https://doi.org/10.5114/kitp.2019.83944 


\title{
Obrazac antimikrobne osetljivosti oralnih viridans streptokoka kod dece sa rizikom od infektivnog endokarditisa
}

\author{
Morva Moudi ${ }^{1}$, Nilgoon Pasdar², Kazem Babazadeh³, Zahra Shahandeh ${ }^{4}$, Farahnaz Sadighian ${ }^{5}$ \\ ${ }^{1}$ Studentski istraživački komitet, Univerzitet medicinskih nauka u Babolu, Babolu, Iran \\ ${ }^{2}$ Istraživački centar za oralno zdravlje, Zdravstveni istraživački institut, Univerzitet medicinskih nauka u Babolu, Babol, \\ Iran \\ ${ }^{3}$ Univerzitet medicinskih nauka u Babolu, Babol, Iran \\ ${ }^{4}$ Istraživački centar za nezarazne dečije bolesti, Zdravstveni istraživački institut, \\ Univerzitet medicinskih nauka u Babolu, Babol, Iran \\ ${ }^{5}$ Departman za laboratorijske nauke, Fakultet paramedicinskih nauka, Univerzitet medicinskih nauka u Babolu, Babol, \\ Iran
}

\section{S AŽETAK}

Infektivni endokarditis (IE) je važno kliničko oboljenje dece, sa stopom mortaliteta od $11,6 \%$. Profilaksa antibioticima jedna je od najčešće korišćenih metoda kod dece sa rizikom od ove bolesti. Stoga je procena antibiotske rezistencije neophodna $u$ pogledu povećanja ovog trenda. Cilj ove studije bilo je određivanje obrasca osetljivosti oralnih viridans streptokoka izolovanih iz dentalnog plaka dece sa rizikom od infektivnog endokarditisa.

Pedeset jedan uzorak plaka dobijen je od dece uzrasta od tri godine do dvanaest godina, u periodu od aprila do jula 2018. godine. Uzorci su uzeti sterilnim brisem i prebačeni u laboratoriju u moždano-srčanom infuzionom agaru. Uzorci su odmah kultivisani na Kolumbija krvnom agaru. Nakon identifikovanja viridans streptokoka, urađen je test antimikrobne osetljivosti (AST) na Mueller-Hinton agaru (MHA) sa ovčijom krvlju i E-test trakama za određene antibiotike. Minimalna inhibitorna koncentracija (MIC) određena je za svaki uzorak i dobijeni rezultati ocenjeni su kao osetljivi, intermedijarno osetljivi i rezistentni.

Izolovana je 51 bakterija iz grupe viridans od dece prosečne starosti 7,3 godine $\pm 2,5$ godina. Najveća rezistencija zabeležena je za azitromicin u $36(70,6 \%)$ izolata, a potom za cefazolin u $35(68,6 \%)$ izolata. Najveća osetljivost uočena je za amoksicilin u 46 (90,2\%) izolata.

Na osnovu nalaza ove studije, amoksicilin je najefikasnija opcija za profilaksu dece. Štaviše, cefazolin treba koristiti oprezno, jer bakterije koje su rezistentne na ovaj antibiotik mogu biti prenosioci rezistentnih gena drugim bakterijama.

Ključne reči: endokarditis, bakterije, nega zuba kod dece, viridans streptokoke, test mikrobne osetljivosti, antibakterijski agensi 